9 Abstract

\title{
On the oxy-combustion of lignite and corn stover in a lab-scale fluidized bed reactor
}

\author{
Carlos Lupiáñeza, M. Carmen Mayoral ${ }^{\mathrm{b}}$, Luis I. Díezª, Eloy Pueyoa, \\ Sergio Espatoleroa, J. Manuel Andrés ${ }^{b}$ \\ a CIRCE, University of Zaragoza, Mariano Esquillor 15, 50018 Zaragoza, Spain \\ b Instituto de Carboquímica-CSIC, Miguel Luesma 4, 50018 Zaragoza, Spain
}

This paper addresses an experimental investigation concerning oxycombustion of coal and biomass in a lab-scale fluidized bed reactor. While co-firing has been widely studied under conventional air conditions, few experiences are available to date for $\mathrm{O}_{2} / \mathrm{CO}_{2}$ atmospheres. The research is focused on $\mathrm{SO}_{2}$ and $\mathrm{NO}_{\mathrm{x}}$ emissions, along with the deposition rates and ashes mineralogy. The influences of the atmosphere (air vs. 30/70\% $\mathrm{O}_{2} / \mathrm{CO}_{2}$ ), the coal-to-biomass energy input ratio $(80 / 20 \%, 90 / 10 \%)$, the chlorine mass fraction in the biomass $(0.35 \%, 1 \%, 2 \%)$ and the Ca:S mole ratio $(2.5,4)$ are reported and discussed in the paper, for two specific fuels: high sulfur lignite and high chlorine corn stover. Concerning $\mathrm{SO}_{2}$ emissions a correlation among the sulfur and the chlorine contents is clearly detected, being affected by the direct desulfurization mechanism occurring under oxy-firing conditions. The single effect of the chlorine content is found to be almost $1.5 \%$ of the desulfurization efficiency. $\mathrm{NO}_{\mathrm{x}}$ emissions are otherwise more dependent on oxygen excess and $\mathrm{CO}$ concentration in the reactor, rather than the fuel share or the chlorine supplied. Thick deposition is only detected when chlorine content in the corn is $2 \%$. Potassium

\footnotetext{
${ }^{1}$ Corresponding author, e-mail address: luisig@unizar.es
} 
27 aluminosilication is found to be enhanced in comparison to potassium sulfation under oxy-firing, especially for the highest Ca:S mole ratio: observed aluminosilication is five times higher when Ca:S ratio is increased

30 from 2.5 to 4 . A significant enrichment in iron is also detected for the fly ash composition, with an increase of $30-50 \%$ in comparison to air combustion.

Keywords

34 Emissions, Deposition, Ashes, Co-firing, Bio-CCS, Fluidized beds; Lignite; Zea mays stover

\section{Introduction}

During the last ten years, oxy-fuel combustion has been proven to be a driving technology towards zero emission power plants [1]. Successful experiences have been reported in pulverized-fuel facilities, as Schwarze Pumpe, Ciuden and Callide [2-6]. Application to fluidized bed boilers has also shown promising results in similar scales [7, 8], with the inherent advantages of wide fuel flexibility and low pollutant emissions. According to these developments, oxy-combustion units are ready to get a commercial scale [9].

More recently, biomass has been proposed to be used as main or secondary fuel in oxy-fired units, aiming to develop bio-CCS (Carbon Capture and Storage with biofuels) [10, 11]. While conventional combustion of biomass has been extensively studied [12-14], few oxy-combustion experiences are available to date [15]. The permanent disposal of $\mathrm{CO}_{2}$ from the combustion of residual biomass contributes to remove $\mathrm{CO}_{2}$ from the atmosphere, leading to the so-called negative emissions. This enhances the attractiveness of the oxy-combustion technologies.

In comparison to coal, firing biomass shows several challenges mainly related to its chemical composition, strongly affected by issues like harvesting, soil residues or use of fertilisers [16]. Main operational problems 
are related to the presence of alkalis and chlorine, which promote deposition on heat transfer surfaces and can also yield long-term corrosion [17-20].

Co-firing of coal and biomass can be considered as an intermediate way to mitigate these problems [21], also enabling the feeding of biomass into larger units [22]. Nevertheless, the synergies between the mineral matters of the fuels have to be well determined. The presence of the sulfur in the coal promotes the reactions between sulfur oxides and alkali chlorides, yielding chlorine-free deposits; the reactions (R.1) and (R.2) show this effect:

$$
\begin{array}{cc}
2 \mathrm{MCl}+\mathrm{SO}_{2}+1 / 2 \mathrm{O}_{2}+\mathrm{H}_{2} \mathrm{O} \rightarrow \mathrm{M}_{2} \mathrm{SO}_{4}+2 \mathrm{HCl} & \text { R. } 1 \\
2 \mathrm{MCl}+\mathrm{SO}_{3}+\mathrm{H}_{2} \mathrm{O} \rightarrow \mathrm{M}_{2} \mathrm{SO}_{4}+2 \mathrm{HCl} & \text { R. } 2
\end{array}
$$

Following this reduction mechanism, Kassman et al. [23, 24] reported the effect of injecting ammonium sulfate, resulting in a decrease of the chlorine detected in the deposits. $\mathrm{SO}_{2}$ oxidation rate (to $\mathrm{SO}_{3}$ ) was suggested by these authors as the limiting factor for the alkali sulfation, since reaction R.2 eventually controls the process.

On the other hand, alkalis can also be competitively retained in the coal ashes by silication or aluminosilication [21], releasing chlorine to the gasphase as $\mathrm{HCl}$, according to the reactions (R.3) and (R.4):

$$
\begin{array}{cc}
2 \mathrm{MCl}+\mathrm{nSiO}_{2}+\mathrm{H}_{2} \mathrm{O} \rightarrow \mathrm{M}_{2} \mathrm{O} \cdot n \mathrm{SiO}_{2}+2 \mathrm{HCl} & \text { R. } 3 \\
2 \mathrm{MCl}+\left(\mathrm{nSiO}_{2}+\mathrm{Al}_{2} \mathrm{O}_{3}\right)+\mathrm{H}_{2} \mathrm{O} \rightarrow 2 \mathrm{MAlSi}_{n / 2} \mathrm{O}_{(n+2)}+2 \mathrm{HCl} & \text { R. } 4
\end{array}
$$

According to the results given by Sevonius et al. [25], the extent of reaction R.3 is very small at fluidized bed conditions and most of alkali retention is due to aluminosilication.

Few results are available in literature concerning co-firing under $\mathrm{O}_{2} / \mathrm{CO}_{2}$ atmospheres, most devoted to pulverized-fuel burners. Fryda et al. [26] pioneered the research on ash deposition under oxy-fuel conditions, finding out an increase of deposition ratios in comparison to air conditions, but 
82 barely affecting the ashes composition. Riaza et al. [27] studied the co-firing 83 of coal and olive residues in an entrained flow reactor, under a variety of $84 \mathrm{O}_{2} / \mathrm{CO}_{2}$ atmospheres. They reported an improvement of ignition 85 temperature when biomass was added, and an opposite trend for $\mathrm{NO}_{\mathrm{x}}$ emissions: increasing for semi-anthracite but decreasing for bituminous coals. Similar results were reported by Ahn et al. [28]. According to the scheme given by reactions (R.1) and (R.2), Ekvall et al. [29, 30] and Jurado et al. [31] respectively found an increase of $\mathrm{K}_{2} \mathrm{SO}_{4}$ in deposits and a decrease of $\mathrm{SO}_{2}$ under oxy-firing of coal and biomass.

As concerns the experiences in fluidized bed combustors, most have been focused on emissions. Tan et al. [32] oxy-fired coal and wood pellets, showing a NO decrease with the biomass-to-coal ratio, without a conclusive trend for the $\mathrm{SO}_{2}$. Duan et al. [33] found that $\mathrm{NO}$ emissions were strongly dependent on $\mathrm{O}_{2}$ excess and $\mathrm{O}_{2}$ primary/secondary split, as also happens for coal air- and oxy-firing.

This paper aims at widening the knowledge about oxy-firing of coal and biomass in fluidized bed reactors, focusing the analysis on emissions but also on the behaviour of the solid-phase: deposition ratios and composition, and ashes characterization. This is done for blends of two risky fuels, highsulfur lignite and high-chlorine corn stover, leading to novel results not available up to now.

\section{Experimental setup}

\subsection{Facility}

The tests were conducted in the fluidized bed reactor at CIRCE Laboratories (Figure 1). The reactor is $2.5 \mathrm{~m}$ height and its inner diameter is $0.203 \mathrm{~m}$. Fuel is fed from two independent hoppers, discharging into two variable-speed endless screws. Bed temperature is regulated by watercooled probes, which can be inserted/extracted on-load. Further details of the facility can be found elsewhere [34-36]. 
The installation is instrumented with temperature, pressure and flow meters, providing real-time information about the unit performance. Flue gas composition $\left(\mathrm{CO}_{2}, \mathrm{CO}, \mathrm{NO}, \mathrm{SO}_{2}, \mathrm{O}_{2}\right)$ is also available, by sampling and analysing at the heat exchanger outlet.

An air-cooled deposition probe can be introduced over the splash zone, in order to characterize the deposits. Probe temperature is controlled to maintain a value within $450-500^{\circ} \mathrm{C}$. A removable coupon is inserted in the tip of the probe, in order to proceed with a subsequent SEM/EDX analysis. Solid samples can be taken during the experiments from the bed bottom, the baffle chamber and the cyclone.
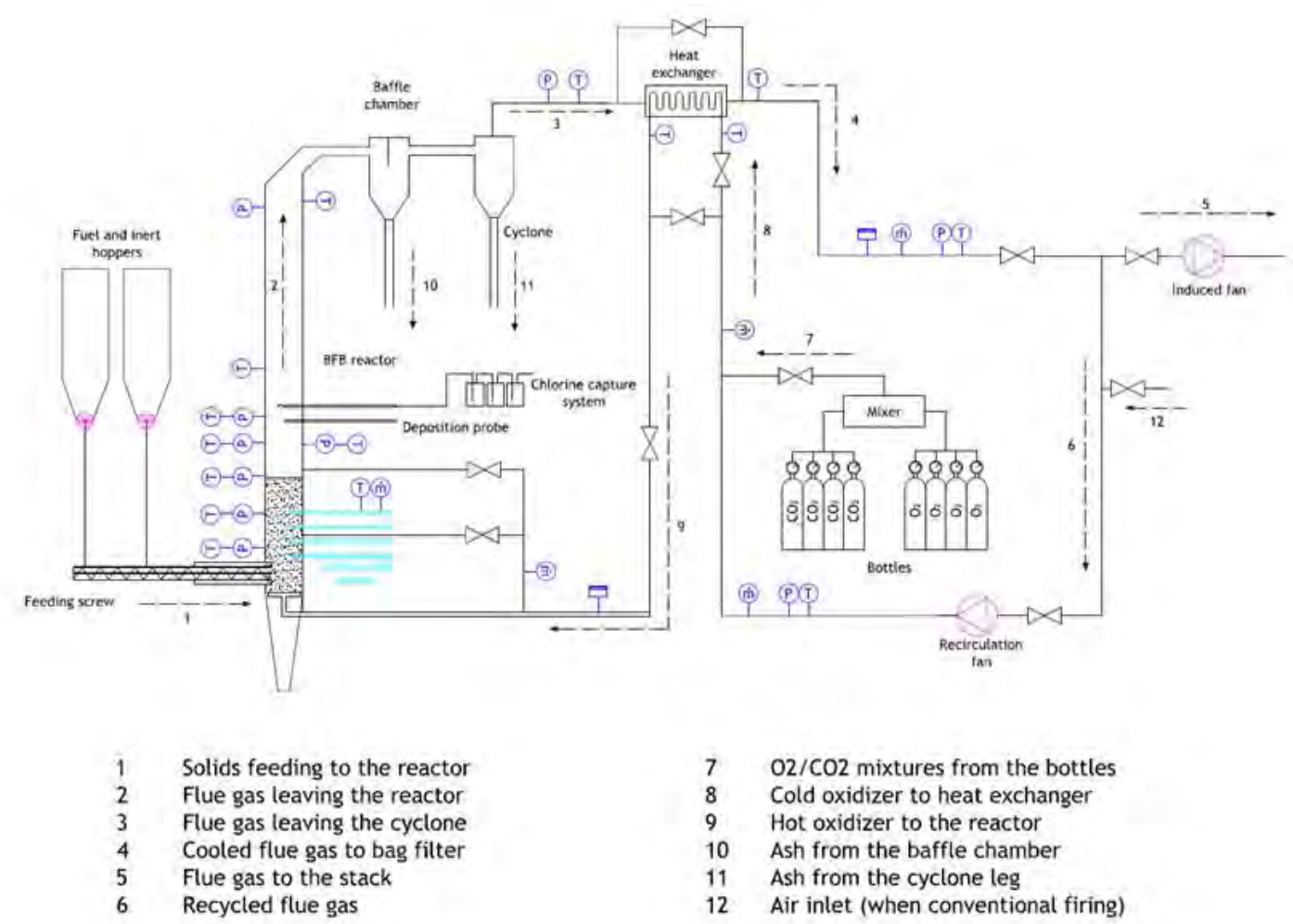

O2/ $\mathrm{CO} 2$ mixtures from the bottles

Cold oxidizer to heat exchanger

Hot oxidizer to the reactor

Ash from the baffle chamber

Ash from the cyclone leg

Air inlet (when conventional firing)

Figure 1.- Oxy-fired fluidized bed facility.

The presence of chlorine in the gas-phase can be determined by conveying samples through three $\mathrm{Na}_{2} \mathrm{CO}_{3}$ impingers. The sample withdrawal is carried out at $0.9 \mathrm{~m}$ over the distributor plate. After every experiment, the contents of the impingers are analysed by ion chromatography (IC) in order to determine the chloride concentration. 
The fuels selected for the experimental campaign were lignite and corn

132 stover. The former is high-sulfur, high-ash coal with large reserves in Spain.

133 The latter is an agricultural residue, selected to seek the interactions among

134 chlorine and sulfur compounds.

135

Lignite Corn Stover

\begin{tabular}{|c|c|c|}
\hline \multicolumn{3}{|c|}{ Mass fractions (\%) as received } \\
\hline Water & 13.57 & 6.18 \\
\hline Ash & 30.30 & 5.50 \\
\hline Chlorine & - & 0.35 \\
\hline LHV as received (MJ kg-1) & 14.43 & 15.44 \\
\hline \multicolumn{3}{|l|}{ Proximate analysis } \\
\hline Volatiles & 45.82 & 80.03 \\
\hline Fixed carbon & 54.18 & 19.97 \\
\hline \multicolumn{2}{|l|}{ Ultimate analysis } & \\
\hline $\mathrm{C}$ & 72.21 & 49.03 \\
\hline $\mathrm{H}$ & 5.67 & 6.59 \\
\hline $\mathrm{N}$ & 0.50 & 0.65 \\
\hline $\mathrm{S}$ & 11.85 & 0.12 \\
\hline \multicolumn{3}{|c|}{$\begin{array}{l}\text { Ash oxide mass fractions (\%) } \\
\text { determined by ICP }\end{array}$} \\
\hline $\mathrm{Al}_{2} \mathrm{O} 3$ & 26.01 & 1.36 \\
\hline $\mathrm{CaO}$ & 3.27 & 8.72 \\
\hline $\mathrm{Fe}_{2} \mathrm{O} 3$ & 22.23 & 6.08 \\
\hline $\mathrm{K}_{2} \mathrm{O}$ & 0.92 & 27.90 \\
\hline $\mathrm{MgO}$ & 0.96 & 3.27 \\
\hline $\mathrm{Na}_{2} \mathrm{O}$ & 0.12 & 0.22 \\
\hline $\mathrm{SiO}_{2}$ & 41.06 & 29.81 \\
\hline $\mathrm{TiO}_{2}$ & 0.76 & 0.80 \\
\hline $\mathrm{P}_{2} \mathrm{O}_{5}$ & - & 3.81 \\
\hline $\mathrm{MnO}_{2}$ & - & 0.14 \\
\hline
\end{tabular}

Table 1.- Fuel analysis, heating value and ash composition. 
The coal was supplied by a Spanish mining company. The coalfield is 139 located close to Ariño (Teruel, Spain). The coal was sent to an Italian 140 company in order to mill and sieve it to the required size. Round-trip 141 transportation was done by truck. Once received back, chemical analysis was conducted to random samples of the coal, yielding proximate and

143 ultimate analyses as well as heating values and ash composition (shown in

144 Table 1). According to the classification given by the standard ASTM D388, 145 the coal type is lignite. Its size was in the range $0.3-1 \mathrm{~mm}$, with a mean 146 diameter of $0.7 \mathrm{~mm}$.

147 The corn stover was supplied by a local farmer from Villamayor 148 (Zaragoza, Spain). Geo-coordinates of the field are $41^{\circ} 41^{\prime} 17^{\prime \prime} \mathrm{N}, 0^{\circ} 45^{\prime} 45^{\prime \prime} \mathrm{W}$. 149 Soil type is silty clay. The specific variety of Zea mays is unknown. Sowing 150 was done during the early spring and harvesting during the early fall (year 151 2013). Corn stover bales were stored indoors by the farmer. We directly picked up and transported the bales from the field to the lab building. Since

153 Zea mays cultivars cannot be completely specified, there is a reasonable concern that there may be factors that influence the results obtained, and for this reason the work cannot be independently reproduced. But the authors believe that the research exemplifies the effect of the inorganic constituents of both the coal and corn.

158 Corn stover was milled and sieved between $1 \mathrm{~mm}$ and $2 \mathrm{~mm}$. Roughly, 159 half of the initial mass was retained for the experiments. Chemical analysis was conducted to random samples of the sieved stover (results shown in Table 1). Fuels were separately stored in closed containers inside the lab

162 building, at room temperature. The same was done with the limestone and 163 the silica sand used in the tests.

The chlorine content in the corn stock (0.35\%) was relatively low in comparison to the values reported in other works [37-39]. For this reason, original corn stover was doped with $\mathrm{KCl}$, increasing the chlorine mass 167 fraction to $1 \%$ and $2 \%$. This consequently increased the content of mineral 168 matter in the corn stover (to $6.80 \%$ and $8.80 \%$ respectively), while the rest of 169 the proximate and ultimate fractions were reduced in proportion. To exclude 
170 the effect of the moisture and the ash contents in the fuels, compositions in

171 Table 1 are expressed in dry and ash-free basis.

172 In order to control $\mathrm{SO}_{2}$ emissions, Granicarb limestone was added during 173 the tests in different Ca:S mole ratios. This limestone is commercialized by a 174 gravel plant located at Belchite (Zaragoza, Spain). Granicarb limestone is 175 characterized by its high purity and reactivity $\left(\mathrm{CaCO}_{3}>97 \%\right)$. Limestone mean size was $0.6 \mathrm{~mm}$. Silica sand $\left(\mathrm{SiO}_{2}>99 \%\right)$ was used as inert material in the bed, with mean particle size similar to limestone. Bed height was maintained around $400 \mathrm{~mm}$ for all the tests.

\subsection{Experimental matrix}

Six experiments were conducted, according to the conditions given in Table 2. The matrix was defined to make possible the discussion of every independent influence. Air and oxy-fired (30/70\% volume fractions $\mathrm{O}_{2} / \mathrm{CO}_{2}$ ) tests were completed, for a similar thermal input (about $22 \mathrm{~kW}$ ). The fuels were blended in 80/20\% and 90/10\% coal-to-stover (LHV) ratios, firing three different corn stover samples. Two different Ca:S mole ratios were also tested, 2.5 and 4.

The facility is preheated by a propane burner up to $T_{\text {bed }} \sim 500^{\circ} \mathrm{C}$, and then an air-combustion stage quickly raises the temperature to $T_{\text {bed }} \sim 850^{\circ} \mathrm{C}$. Then, the firing is switched to $\mathrm{O}_{2} / \mathrm{CO}_{2}$ atmosphere. Once the operation is stable, deposition probe is inserted and chlorine-capture device is turned on. Operating data were gathered every two seconds during at least one hour and a half of steady-state conditions.

\subsection{Analytical techniques}

Hitachi S-3400N microscope equipped with a SDD-EDX detector Rontec XFlash was used to determine the composition and morphology of the particles taken from different sections of the facility (bed bottom, deposition probe, baffle chamber, cyclone). For that, a portion of each sample was disposed onto the holder carbon tape, micrographs were taken with the microscope and areas of interest were chosen for EDX analysis. For solid 
202 mixtures as those found in the bed bottom, a number of particles were 203 selected (five from each type: sand, sorbent and ash), and composition of a 204 rectangular area of image was recorded. For finer powders as fly ash or 205 deposits, areas of interest were selected from SEM images to perform the 206 EDX analysis ensuring complete characterization.

207 The composition of the crystalline species was given by X-ray diffraction 208 (XRD) in a Siemens Bruker D8 Advance Series 2 diffractometer, set to select $209 \mathrm{Cu} \mathrm{Ka}$ radiation. The diffraction angle scanned was 20-70 $2 \theta$ using a step 210 size of $0.05^{\circ} 2 \theta$. Ion Chromatography (IC) was used to detect the presence of 211 soluble chlorides in the traps.

\begin{tabular}{lrrrrrr}
\hline & A1 & OXY1 & OXY2 & OXY3 & OXY4 & OXY5 \\
\hline Fluidizing gas, volume & Air & $30 / 70$ & $30 / 70$ & $30 / 70$ & $30 / 70$ & $30 / 70$ \\
fractions & & & & & & \\
Coal-to-biomass energy & $80 / 20$ & $80 / 20$ & $80 / 20$ & $90 / 10$ & $80 / 20$ & $80 / 20$ \\
input ratio & & & & & & \\
Ca:S mole ratio & 2.5 & 2.5 & 2.5 & 2.5 & 4 & 4 \\
Chlorine mass fraction $(\%)$ & 1 & 1 & 2 & 1 & 0.35 & 1 \\
\hline $\mathrm{T}_{\text {bed }}\left({ }^{\circ} \mathrm{C}\right)$ & 876 & 856 & 859 & 852 & 851 & 862 \\
$\mathrm{~T}_{\mathrm{fb}}\left({ }^{\circ} \mathrm{C}\right)$ & 638 & 637 & 621 & 563 & 589 & 605 \\
$\mathrm{u}\left(\mathrm{m} \mathrm{s}{ }^{-1}\right)$ & 1.18 & 0.82 & 0.80 & 0.74 & 0.70 & 0.72 \\
$\mathrm{O}_{2}(\%)$ & 5.66 & 5.85 & 5.34 & 3.42 & 1.61 & 2.31 \\
$\mathrm{CO}\left(\mathrm{mg} \mathrm{m}^{-3}\right)$ & 1139 & 746 & 863 & 473 & 417 & 908 \\
$\mathrm{NO}^{\left(\mathrm{mg} \mathrm{m}^{-3}\right)}$ & 240 & 343 & 348 & 514 & 504 & 289 \\
$\mathrm{NO}^{\left(\mathrm{mg} \mathrm{MJ}^{-1}\right)}$ & 46 & 37 & 40 & 59 & 54 & 33 \\
$\mathrm{SO}_{2}\left(\mathrm{mg} \mathrm{m}^{-3}\right)$ & 2207 & 12155 & 11078 & 13493 & 9790 & 8671 \\
$\mathrm{SO}_{2}\left(\mathrm{mg} \mathrm{MJ}^{-1}\right)$ & 455 & 1413 & 1382 & 1684 & 1111 & 1073 \\
$\mathrm{Desulfurization} \mathrm{eff.}(\%)_{\mathrm{Cl}}^{-}\left(\mathrm{mg} \mathrm{m}^{-3}\right)$ & 87.7 & 61.7 & 62.9 & 59.5 & 70.2 & 71.4 \\
& 66.06 & 62.78 & 149.67 & 61.28 & 7.91 & 89.06 \\
\hline
\end{tabular}

214 Table 2.- Operating conditions during the tests. $\mathrm{CO}, \mathrm{NO}$ and $\mathrm{SO}_{2}$ corrected to 215 $6 \% \mathrm{O}_{2}$ and Normal conditions (273 K and $101.3 \mathrm{kPa}$ ) 
218 3. Results and discussion

2193.1 Gas-phase

220 Table 2 shows the mean values of the flue gas composition $\left(\mathrm{O}_{2}, \mathrm{CO}, \mathrm{NO}\right.$, $221 \mathrm{SO}_{2}$ ), the operating temperatures and the fluidization velocities during 222 every test, and as well as chlorine concentrations in the gas-phase and 223 desulfurization efficiencies. Bed temperature was maintained within $224850-880^{\circ} \mathrm{C}$, while $\mathrm{O}_{2}$ concentration in flue gases mostly depended on the 225 air/gas flowrate supplied to the reactor, which is proportional to the 226 fluidization velocity. Under oxy-firing conditions, fluidization velocities were 227 in the range $0.70-0.82 \mathrm{~m} \mathrm{~s}^{-1}$. Velocity was higher under air-firing conditions $228(1.18 \mathrm{~m} / \mathrm{s})$, since the lower $\mathrm{O}_{2}$ concentration $(21 \%$ vs. $30 \%)$ requires an 229 increase the air flowrate supplied for the same fuel load.

\subsection{1 $\mathrm{SO}_{2}$ and $\mathrm{NO}$ emissions}

Taking into account the fuel rate supplied and the $\mathrm{SO}_{2}$ concentration in 232 flue gases, desulfurization efficiency was calculated after the tests. A value 233 of $87.7 \%$ was obtained for the air-fired test, which is in good agreement with 234 previous experience [35, 40]. It is clearly seen in the Table 2 that 235 desulfurization efficiency drops during oxy-fired tests (16-28\% efficiency 236 points). This can be explained by the different sulfation processes taking 237 place in the reactor. Under air-firing conditions, desulfurization takes place 238 by means of an indirect capture mechanism. Firstly, limestone is calcined 239 and then, the resulting $\mathrm{CaO}$ is sulfated (R.5 and R.6):

$$
\begin{array}{cc}
\mathrm{CaCO}_{3} \leftrightarrow \mathrm{CaO}+\mathrm{CO}_{2} & \text { R. } 5 \\
\mathrm{CaO}+\mathrm{SO}_{2}+1 / 2 \mathrm{O}_{2} \rightarrow \mathrm{CaSO}_{4} & \text { R. } 6
\end{array}
$$

However, the conditions tested during oxy-fired tests $\left(70 \% \mathrm{CO}_{2}, T_{\mathrm{b}} \sim\right.$ $850^{\circ} \mathrm{C}$ ) imply a shift of the desulfurization mechanism. Limestone is not calcined, taking place the so-called direct desulfurization:

$$
\mathrm{CaCO}_{3}+\mathrm{SO}_{2}+1 / 2 \mathrm{O}_{2} \rightarrow \mathrm{CaSO}_{4}+\mathrm{CO}_{2}
$$


The direct mechanism has been reported to result in lower desulfurization efficiencies by other researchers [41, 42], which is consistent with the numbers shown in Table 2. Therefore, operation of oxy-fired fluidized bed would require an increase of the Ca:S ratio in comparison to the experiences available for air-fired units. This is confirmed by the values in Table 2: if OXY1 is compared to OXY5, an efficiency increase of almost $10 \%$ efficiency points is observed when increasing Ca:S ratio from 2.5 to 4 (the rest of conditions remaining the same).

$\mathrm{SO}_{2}$ emissions are also affected by the chlorine content supplied with the biomass. The higher the chlorine, the lower the $\mathrm{SO}_{2}$ emitted, as can be seen if test OXY1 (1\%) is compared to OXY2 (2\%), or OXY4 (0.35\%) to OXY5 (1\%). This can be a consequence of alkali sulfation (R.1 and R.2), as discussed hereinafter.

As concerns actual NO emissions ( $\mathrm{mg} \mathrm{m}^{-3}$, in Normal conditions), the lowest value is detected during the air-fired tests, provided that the flue gas flowrate $\left(\mathrm{m}^{3} \mathrm{~s}^{-1}\right)$ is higher $[43,44]$. Furthermore, air operation results in the top value for $\mathrm{CO}$ emissions, which is known to contribute to NO depletion (by direct reduction or by catalysing the heterogeneous reaction char + NO) 261

$$
\begin{gathered}
\mathrm{NO}+\mathrm{CO} \rightarrow \mathrm{CO}_{2}+1 / 2 \mathrm{~N}_{2} \\
C_{\text {char }}+\mathrm{NO} \rightarrow \mathrm{CO}+1 / 2 \mathrm{~N}_{2}
\end{gathered}
$$

The highest value of $\mathrm{CO}$ concentration observed for the air-fired test can be explained by the fluidization velocity, yielding a lower residence time of the particles in the dense zone. In general, a good correlation can be observed between $\mathrm{CO}$ concentration and fluidization velocity, except for the test OXY5. This is not due to either the chlorine content in the corn or the $\mathrm{Ca}: \mathrm{S}$ mole ratio, but to some uncontrolled instabilities in the fuel supply during the last test.

To avoid the effect of the different flue gas flowrates, emissions are usually compared in normalized units ( $\mathrm{mg} \mathrm{MJ}-1$ ). The reason relies on the 
different $\% \mathrm{O}_{2}$ contents that can be supplied with the gas mixture $\mathrm{O}_{2} / \mathrm{CO}_{2}$ as explained before. On the contrary to air combustion (fixed $21 \% \mathrm{O}_{2}$ ), oxycombustion can be conducted with enriched $\mathrm{O}_{2}$ concentrations. The rising of the $\mathrm{O}_{2}$ concentration means a decrease of the supplied $\mathrm{O}_{2} / \mathrm{CO}_{2}$ total flowrate - for the same stoichiometric ratio, i.e. oxygen excess - and consequently a decrease of the flue gases flowrate.

If comparison is therefore done in normalized units ( $\left.\mathrm{mg} \mathrm{MJ}^{-1}\right)$, then oxyfired test OXY1 results in lower NO emissions than air-fired test A1 despite the higher $\% \mathrm{O}_{2}$ supplied (the rest of conditions remaining the same). This trend is commonly found in open literature and it is explained by the high $\mathrm{CO}_{2}$ concentration in the dense phase, contributing to an increase of char gasification, release of $\mathrm{CO}$ and subsequent NO reduction [40, 48, 49]. Guedea et al. [50] estimated the effect of gasification as an increase of $5-15 \%$ of the initial solid conversion in comparison to air conditions, for typical particle sizes in fluidized beds. Czackiert et al. [51] reported that CO represented $20 \%$ of the carbon conversion in the dense zone, for similar operating conditions $\left(\mathrm{O}_{2} / \mathrm{CO}_{2}\right.$ atmosphere, temperature).

On the other hand, it is well known that free $\mathrm{CaO}$ catalyses NO formation [52], but this effect was very limited during our oxy-fired tests. According to the experimental values $\left(\% \mathrm{CO}_{2}\right.$ and bed temperatures), the tests were conducted under non-calcining conditions and then the presence of $\mathrm{CaO}$ can be considered negligible in comparison to $\mathrm{CaCO}_{3} / \mathrm{CaSO}_{4}$. This is not the case of the air-fired test, in which calcining conditions occurred, being another cause of the higher NO emission in (normalized) comparison to the test OXY1.

No significant influence of corn chlorine content on NO emissions can be observed if test OXY1 is compared to test OXY2: doubling the chlorine supplied, the NO emissions remain almost the same (for similar CO values). The same can be said for the Ca:S ratio: test OXY5 shows a very small reduction of NO emissions in comparison to the test OXY1 (Ca:S = 4 vs. $\mathrm{Ca}: \mathrm{S}=2.5)$. 


\subsubsection{Chlorine concentration}

As explained before, gas samples were conveyed through three impingers in order to detect the chlorine concentration in the gas-phase. This is a useful indicator of the combined extent of sulfation and aluminosilication processes taking place in the reactor, since it is proportional to the $\mathrm{HCl}$ concentration in the gas-phase - also $\mathrm{KCl}$ aerosols and $\mathrm{Cl}_{2}$ can be present in the trapped samples-. Chlorine concentration in the gas-phase (see Table 2) can be qualitatively correlated to the analysis carried out to the solid samples (ashes and deposits).

Chlorine was trapped in all tests, showing almost the same value if only the atmosphere is changed (air vs. $\mathrm{O}_{2} / \mathrm{CO}_{2}$ ). Under oxy-firing, the observed trend is the expected according to the chlorine content in the corn stover: test OXY2 shows the highest value, test OXY4 shows the lowest value. The reduction of the biomass in the fuel blend (10\% OXY3 vs. 20\% OXY1, both with $1 \% \mathrm{Cl}$ ) barely diminishes the chlorine detected in the gas-phase. A significant influence is nevertheless observed if OXY1 and OXY5 are compared, when only $\mathrm{Ca}: \mathrm{S}$ ratio was modified. $\mathrm{Cl}^{-}$concentration raises almost $50 \%$, related to an increase of aluminosilication ratios as discussed in the next section.

\subsection{Solid-phase}

\subsubsection{Bottom bed}

Bottom bed solids collected after the tests are comprised by a mixture of particles rich in calcium (sorbent), particles rich in silica (sand) and particles rich in aluminosilicates (ashes). Surface composition of the three types of solid particles was studied by SEM-EDX, and elemental composition normalized to main elements is shown in Figure 2. 
329

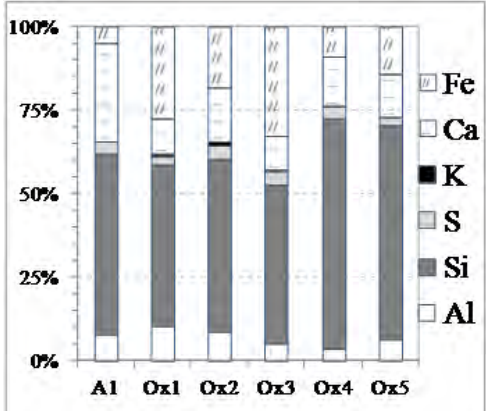

(a) Silica bed particles

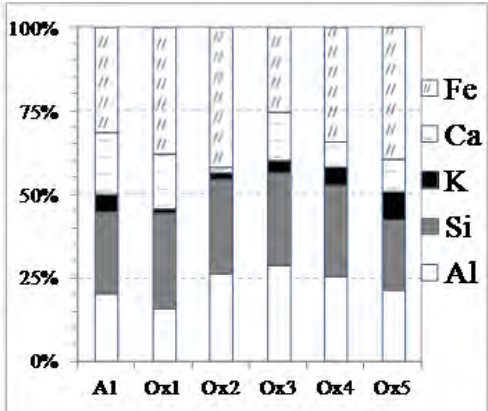

(b) Ash particles

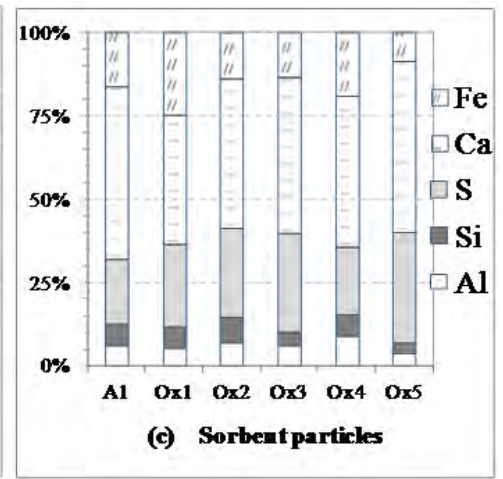

Figure 2.- Normalized composition of bottom bed solids (\% mass fraction) by EDX.

An example of silica sand particles is shown in Figure 3.a, where it is possible to see that they are covered by fine ash from extraneous and inherent fuel mineral matter $(\mathrm{Al}, \mathrm{Fe})$, and fine matter from sorbent ( $\mathrm{S}$ and Ca). Small presence of potassium can be detected in some of the tests.

Coal ash particles are composed by $\mathrm{Al}-\mathrm{Si}$ material and $\mathrm{Ca}$ and $\mathrm{Fe}$ fines, Figure 3.b. No chlorine was detected in the bottom bed ashes during the whole campaign. This was expectable, due to the high volatility of $\mathrm{KCl}$. Some sulfur was self-retained by the ashes, linked to $\mathrm{Ca}$ and Fe.

Particles rich in calcium and sulfur are considered partially sulfated sorbent, see Figure 3.c. Surface composition in Figure 2 is not an accurate indication of sulfation degree since only the external layer is analysed; nevertheless, the information obtained by means of EDX indicates that fine dust is covering the particles composed of aluminosilicate ash from extraneous fuel mineral matter, and iron from inherent lignite mineral matter as pyrite.
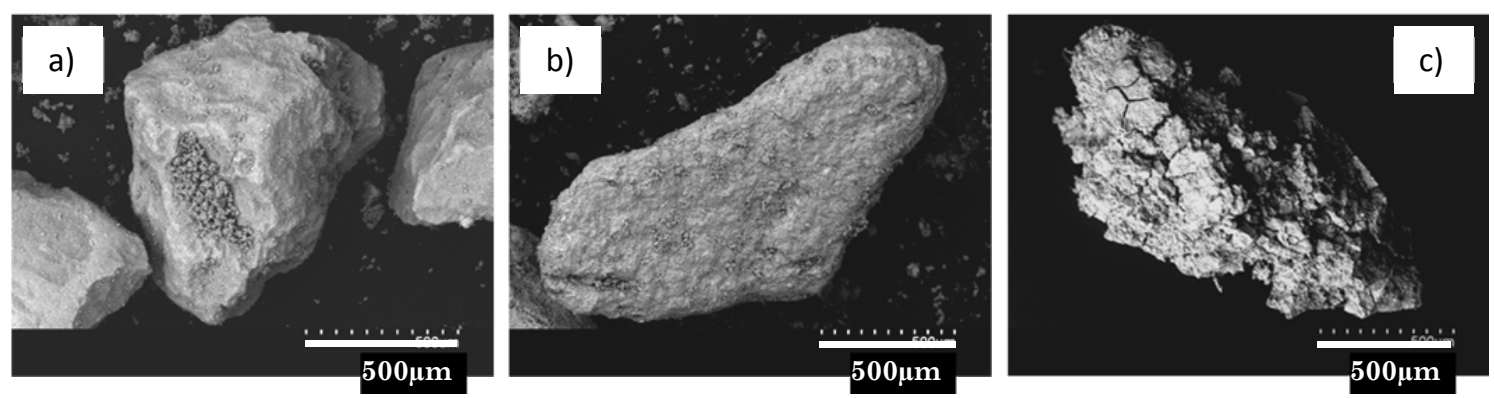

Figure 3.- Bed particles from test A1: (a) silica sand, (b) coal ash, (c) partially sulfated sorbent. 
The most important finding from EDX ash composition is the extent of potassium presence on ash surfaces. To further study the interactions between potassium and bed materials, some XRD analysis were performed to bed solids collected during tests A1 and OXY1. The diffractograms are

353 shown in Figure 4.a. The most intense peak for both samples is quartz, while the presence of sulphated sorbent as $\mathrm{CaSO}_{4}$ is clear. On the other hand, $\mathrm{CaO}$ is present in $\mathrm{A} 1$ solids whereas uncalcined $\mathrm{CaCO}_{3}$ is present for test OXY1 (as expected, due to the different desulfurization mechanism). The diagrams do not identify any specie based on Fe, Al-Si nor species where $\mathrm{K}$ would be chemically bound to aluminosilicates or silica. In fact, calcination of lignite ashes in lab-scale furnace indicates that the original crystalline aluminosilicate mineral matter develops into an amorphous phase, since it is not detected in $850^{\circ} \mathrm{C}$ ashes (Figure $4 . \mathrm{b}$ ). In consequence, EDX composition of surfaces is considered more representative than XRD to the purpose of analysing interactions of different elements in coal and biomass mineral matters.

Table 3 shows K/Si and $\mathrm{K} / \mathrm{Al}$ mole ratios, in order to analyse the interactions among the mineral matter. The ratios $\mathrm{K} / \mathrm{Si}$ and $\mathrm{K} / \mathrm{Al}$ of test $\mathrm{A} 1$ show a clear increase from those values in original coal ash, which points out the incorporation of potassium in amorphous aluminosilicates. Test OXY1 and OXY2 show a slight increase, whereas the increase is outstanding for the cases OXY4 and OXY5 (Ca:S = 4). These results indicate that for those test with high desulfurization efficiency, the reduction of $\mathrm{SO}_{2}$ yields a decrease of alkali sulfation that may involve an increase of potassium aluminosilication in the dense zone, according to reaction R.4. 

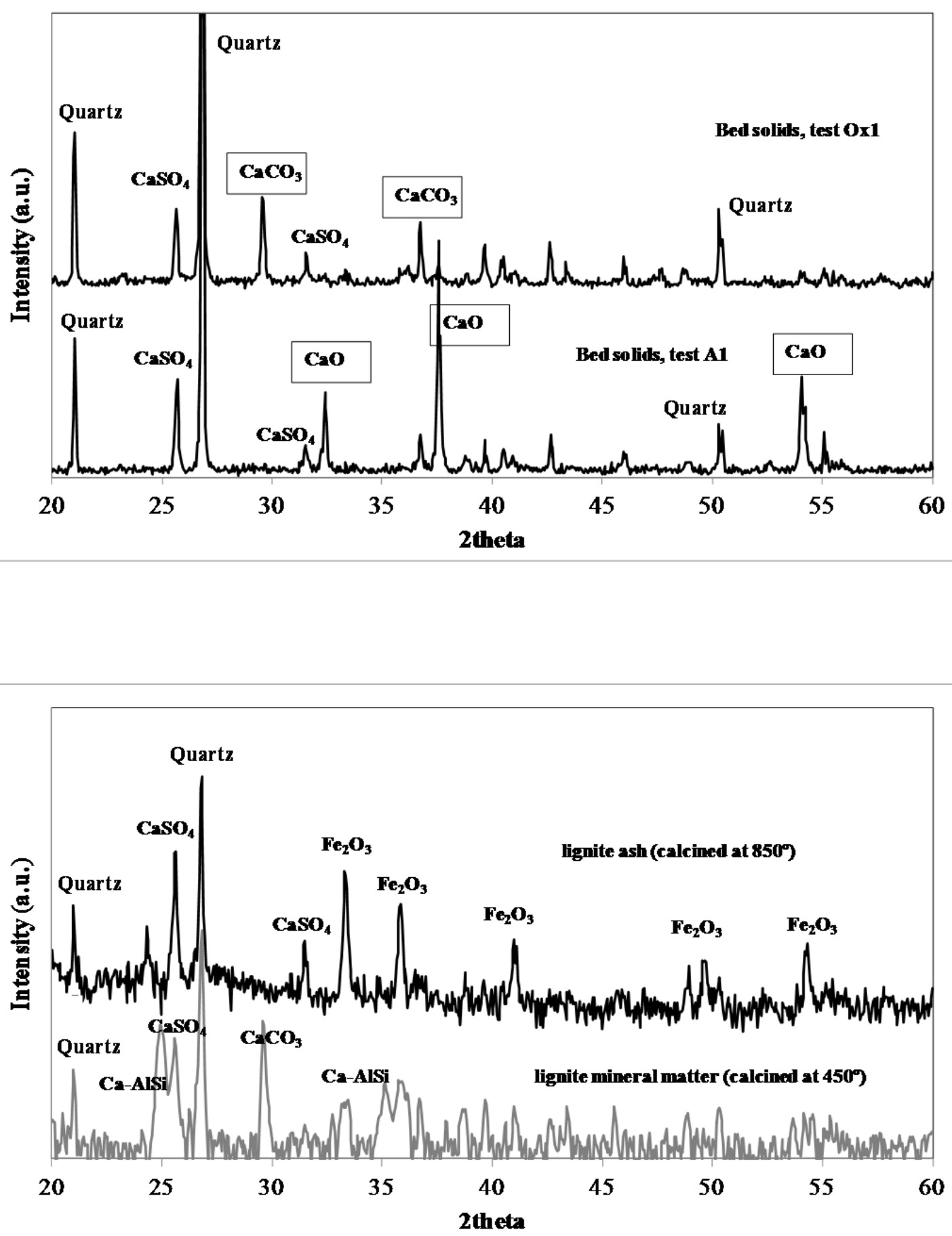
residue after lignite ashing at $450^{\circ}$ and $850^{\circ} \mathrm{C}$. 


\begin{tabular}{cccc}
\hline Test \# & Particles & K/Si & K/Al \\
\hline- & Original coal ash & 0.027 & 0.038 \\
\hline A1 & Bed ashes & 0.149 & 0.175 \\
\hline OXY1 & Bed ashes & 0.031 & 0.056 \\
OXY2 & Bed ashes & 0.049 & 0.051 \\
OXY3 & Bed ashes & 0.093 & 0.087 \\
OXY4 & Bed ashes & 0.131 & 0.136 \\
OXY5 & Bed ashes & 0.293 & 0.272 \\
\hline
\end{tabular}

383 On the other hand, the decrease of biomass in the fuel share in test 384 OXY3 also resulted in an enhancement of potassium aluminosilication, 385 despite the larger $\mathrm{SO}_{2}$ concentration from the coal. This could seem a 386 contradiction, but there is another variable also playing a role: $\mathrm{O}_{2}$ concentration. Several researchers $[24,53]$ have discussed that alkali sulfation is limited by an intermediate reaction, the oxidation of $\mathrm{SO}_{2}$ to $\mathrm{SO}_{3}$. This is a slow reaction at typical fluidized bed temperatures and highly dependent on $\mathrm{O}_{2}$ concentration [54]. Therefore, if $\mathrm{O}_{2}$ concentration diminishes, retention of potassium by aluminosilicates is enhanced in comparison to retention by sulfate.

No agglomeration issues were found during the entire experimental campaign. Formation of agglomerates has been described in literature [55, 56] due to interactions with silica sand, but mostly when full-load is given by firing biomass (or residues). Combination of $\mathrm{SiO}_{2}$ from bed material and

397 low melting point of biomass ash can promote agglomeration of the solids. 398 But this effect has not been observed in our experiments, due to the low feed 399 ratio of biomass (20\% on energy basis) and the high ash content of the 400 lignite (over 30\%). The solids inventory in the bed is then involving a 401 different chemistry. First, there is less apportioning of biomass ashes to the 402 bed and, secondly, reactivity is modified by the significant presence of 403 aluminosilicates from the coal ashes. 
404

405

406

407

408

409

410

411

412

413

414

415

416

417

418

419

420

421

422

423

424

\subsubsection{Fly ash}

EDX composition of a representative sample of fine solids gathered from the cyclone is shown in Table 4 for tests A1, OXY1, OXY2 and OXY5 (onload extraction was not possible during tests OXY3 and OXY4 due to operational constrain). They are a mixture of Al-Si fly ashes, $\mathrm{CaSO}_{4}$ sorbent particles elutriated form the reactor, and an important presence of iron.

\begin{tabular}{cccccccc}
\hline Test\# & Mg & Al & Si & S & K & Ca & Fe \\
\hline A1 & 1.50 & 17.08 & 21.58 & 5.50 & 4.53 & 21.77 & 27.43 \\
\hline OXY1 & 1.90 & 14.84 & 20.18 & 6.04 & 3.22 & 18.07 & 35.76 \\
OXY2 & 1.65 & 14.17 & 18.82 & 5.24 & 3.99 & 15.64 & 40.49 \\
OXY5 & 0.46 & 23.15 & 25.07 & 1.28 & 2.57 & 8.26 & 39.21 \\
\hline
\end{tabular}

Table 4.- Elemental mass fractions (\%) by EDX.

SEM images of fly ashes from OXY1 and OXY5 tests are shown in Figure 5.a. and 5.b. It is possible to see the mixture of different types of solids, where the presence of 20 to $30 \mu \mathrm{m}$ spheres is clearly seen. EDX composition of the spheres determined their composition as iron oxide; their spherical shape indicates that the iron particles from inherent pyrite originally had a molten state, which corresponds to $\mathrm{FeO}-\mathrm{FeS}$ eutectic identified in oxy-combustion of coal [57]. Similar iron morphology is found in OXY1 bottom bed ashes, as shown in Figure 5.c.
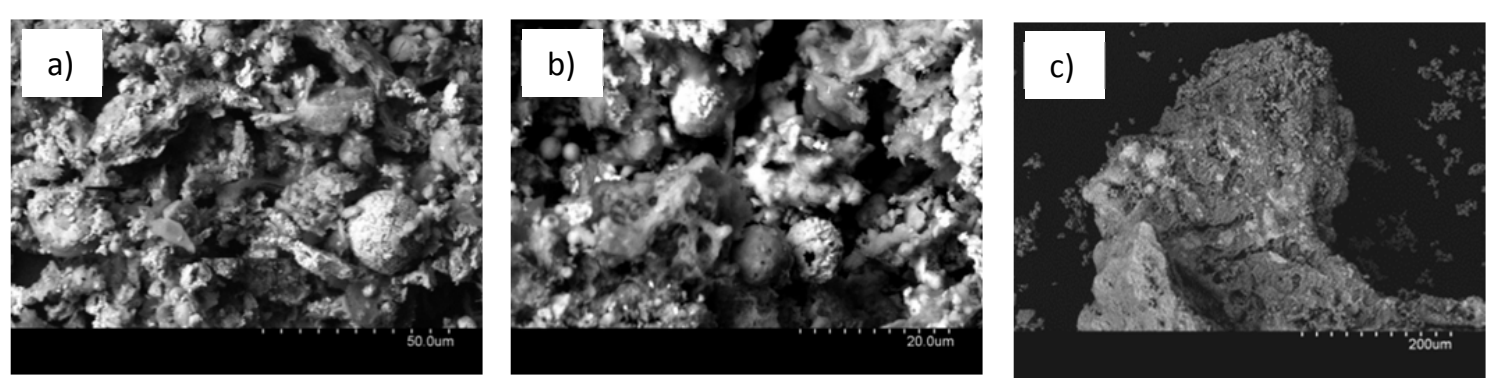

Figure 5.- SEM images of: (a) test OXY1 fly ash, (b) test OXY5 fly ash,

(c) test OXY1 bottom bed ash. 
Table 5 shows the calculation of $\mathrm{K} / \mathrm{Si}$ and $\mathrm{K} / \mathrm{Al}$ indexes according to the ash composition. For test A1 fly ash, the indexes show similar values than those found in bed particles. For the fly ash in oxy-combustion experiments, the trend is opposite to the bottom bed solids, since lower aluminosilication ratios are detected for the test OXY5 in comparison to OXY1. This is meaningful, since the potassium retained in the bed zone is not available beyond the splash zone. The amount of potassium found in fly ash in tests OXY1 and OXY2 can be related to the presence of condensed $\mathrm{K}_{2} \mathrm{SO}_{4}$ onto the elutriated particles.

435

\subsection{Deposits}

Some fuel-related indexes, based on empirical experiences, are widely used to predict the risk of deposition of alkali chlorides onto the heat transfer surfaces in combustion systems. The first index relates the sulfur and chlorine contents, S/Cl. Values over 4 are considered adequate, since alkalis can be sulfated and then chlorine is released to the gas-phase as $\mathrm{HCl}$ [21]. In the case of a fluidized bed reactor, this index has to be calculated 446 taking into account that sorbent is usually added, and then sulfur availability is reduced. In our case, a modified $\mathrm{S} / \mathrm{Cl}$ index has been

448 calculated, taking into account the desulfurization efficiencies reported in 449 Table 2. The second index relates the silicon and aluminium contents to the 
450 sodium and potassium contents, $(\mathrm{Si}+\mathrm{Al}) /(\mathrm{Na}+\mathrm{K})$. Values over 10 are 451 considered promoting potassium aluminosilication, thus avoiding the alkali 452 chloride deposition [58, 59]. Table 6 summarizes the values of these indexes 453 for the combination of fuels and compositions used during the tests, as well 454 as the deposition rate observed in the probe inserted in the reactor. 455 According to the numbers in Table 6, no chlorine should be expected in the 456 deposits, even for the test OXY2 with the highest chlorine content.

\begin{tabular}{ccccc}
\hline Test\# & $\mathbf{S} / \mathbf{C l}$ & $\mathbf{S} / \mathbf{C l}$ & $\mathbf{( A l}+\mathbf{S i}) /(\mathbf{N a}+\mathbf{K})$ & Deposit on probe \\
\hline A1 & 31.57 & 10.78 & 19.39 & No deposits \\
\hline OXY1 & 31.57 & 12.10 & 19.39 & Thin fouling \\
OXY2 & 15.78 & 5.85 & 14.64 & Fouling \\
OXY3 & 74.71 & 30.25 & 30.07 & Thin fouling \\
OXY4 & 90.21 & 26.92 & 24.79 & Thin fouling \\
OXY5 & 31.57 & 9.01 & 19.39 & Thin fouling
\end{tabular}

Table 6.- Fuel-related indexes and deposition rates observed.

460

No deposit was found on the coupon in test A1. Deposits on the probe 462 after the tests OXY1, OXY2 and OXY4 were analysed by SEM-EDX as representative of the three different initial corn compositions (Table 7). The surface analysis confirmed the absence of chlorine. Provided that Fe from coupon surface could overlap Fe content in deposits, elemental composition values were normalized to $\mathrm{Al}, \mathrm{Si}, \mathrm{S}, \mathrm{K}$ and $\mathrm{Ca}$.

467

\begin{tabular}{cccccc}
\hline Test\# & Al & Si & S & K & Ca \\
\hline OXY1 & 9.05 & 12.59 & 35.10 & 33.11 & 10.15 \\
OXY2 & 4.39 & 3.96 & 33.03 & 50.51 & 8.11 \\
OXY4 & 21.37 & 28.39 & 14.37 & 19.35 & 16.51 \\
\hline
\end{tabular}


Deposits in test OXY1 are comprised by a mixture of $\mathrm{K}_{2} \mathrm{SO}_{4}$ and $\mathrm{CaSO}_{4}$ along with some aluminosilicate fines. Morphology of deposit is shown in 472 Figure 6.a, where it is also possible to identify small spheres of iron. For test 473 OXY2 (2\% chlorine in the corn, the most fouled case), the presence of $\mathrm{K}_{2} \mathrm{SO}_{4}$ 474 is clearly detected. Crystals of potassium sulfate can be easily seen in 475 Figure 6.b. No molten deposits were detected. For test OXY4 (0.35\% chlorine 476 in the corn), potassium sulfate is less relevant and aluminosilicates are the major constituent. These results are fully consistent with the chlorine contents in the fuel and the Ca:S ratios supplied during the experiments.
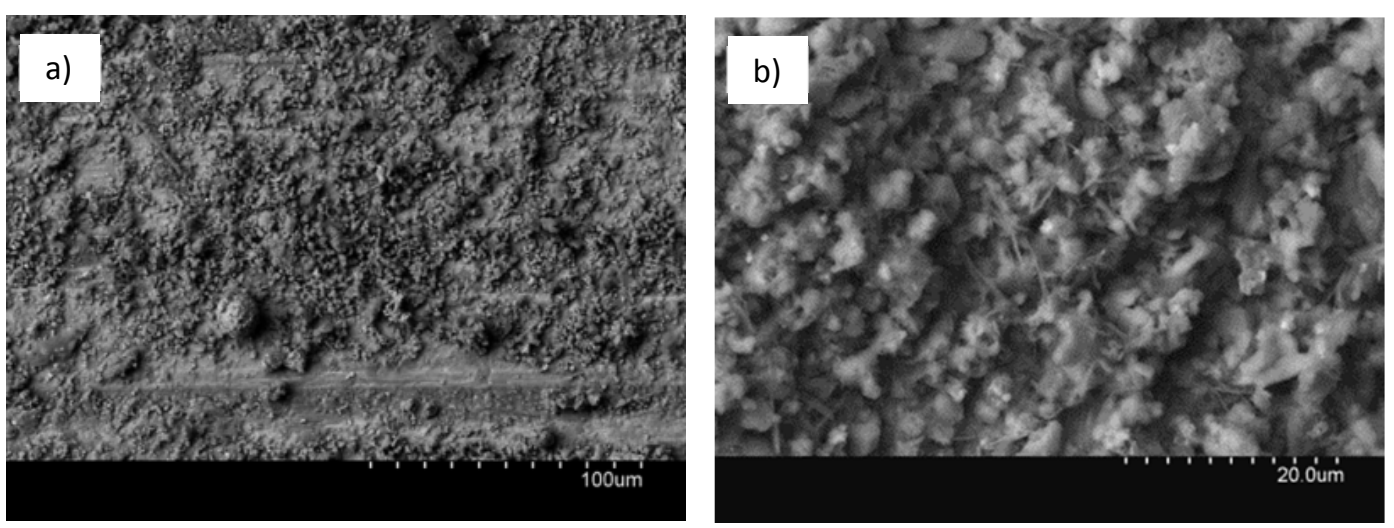

481

Figure 6.- SEM images of deposits: a) test OXY1, b) test OXY2.

482

\section{Conclusions}

$\mathrm{SO}_{2}$ capture efficiency is affected not only by the $\mathrm{O}_{2} / \mathrm{CO}_{2}$ atmosphere, but also by the chlorine content supplied with the biomass. As concerns NO emissions, no relevant biomass-related influences are detected for the conditions tested.

Significant potassium contents in the bottom bed ashes have been found 489 linked to amorphous aluminosilicates, especially for the oxy-fired tests with 490 higher desulfurization efficiencies. As concerns fly ash composition, the 491 presence of potassium is related to condensation of alkali sulfates on the 492 solid surfaces. Oxy-firing largely increases the iron found in ash. 
In relation to the deposits on the probe, no chlorine was detected even for the test with the largest deposition rates. The presence of $\mathrm{K}_{2} \mathrm{SO}_{4}$ in deposits has shown a consistent relation to the $\mathrm{KCl}$ content supplied with the fuel.

The observed results can be representative for large-scale fluidized bed boilers. Despite the differences in fluid dynamics, most of the phenomena addressed in our lab-scale research are related to the chemical conversions in the dense zone, and then comparative trends are meaningful.

\section{Acknowledgements}

The work described in this paper was partially funded by the $R+D$ Funds).

\section{References}

[1] R. Stanger, T. Wall, R. Spörl, M. Paneru, S. Grathwohl, M. Weidmann, et al., Oxyfuel combustion for $\mathrm{CO}_{2}$ capture in power plants, Int. J. Greenh. Gas Control. 40 (2015) 55-125.

[2] T. Wall, R. Stanger, S. Santos, Demonstrations of coal-fired oxy-fuel technology for carbon capture and storage and issues with commercial deployment, Int. J. Greenh. Gas Control. 5 (2011) S5-S15.

[3] T. Yamada, T. Kiga, C. Spero, COP -Operational Resultsof Callide-A Oxyfuel Power Plant, in: $5^{\text {th }}$ Meeting IEAGHG Int. Oxyfuel Combust. Res. Netw., Wuhan (China), 2015.

[4] R. Faber, J. Yan, F. Stark, S. Priesnitz, Flue gas desulphurization for hot recycle Oxyfuel combustion: Experiences from the $30 \mathrm{MW}_{\text {th }}$ Oxyfuel pilot plant in Schwarze Pumpe, Int. J. Greenh. Gas Control. 5 (2011) S210-S223.

[5] M. Anheden, U. Burchhardt, H. Ecke, R. Faber, O. Jidinger, R. Giering, et al., Overview of operational experience and results from test activities in Vattenfall's $30 \mathrm{MW}_{\text {th }}$ oxyfuel pilot plant in Schwarze Pumpe, Energy Procedia. 4 (2011).

[6] M. Lupion, B. Navarrete, P. Otero, V.J. Cortés, Experimental programme in CIUDEN's $\mathrm{CO}_{2}$ capture technology development plant for power generation, 
[7] M. Lupion, R. Diego, L. Loubeau, B. Navarrete, CIUDEN CCS Project: Status of the $\mathrm{CO}_{2}$ capture technology development plant in power generation, Energy Procedia. 4 (2011) 5639-5646.

[8] M. Gómez, A. Fernández, I. Llavona, R. Kuivalainen, Experiences in sulphur capture in a $30 \mathrm{MW}_{\text {th }}$ Circulating Fluidized Bed boiler under oxy-combustion conditions, Appl. Therm. Eng. 65 (2014) 617-622.

[9] S. Santos, Future of Oxyfuel Combustion, in: $5^{\text {th }}$ Oxyfuel Combust. Res. Netw., Wuhan (China), 2015.

[10] P. Gładysz, A. Ziębik, Environmental analysis of bio-CCS in an integrated oxy-fuel combustion power plant with $\mathrm{CO}_{2}$ transport and storage, Biomass and Bioenergy. 85 (2016) 109-118.

[11] S. Pickard, S.S. Daood, W. Nimmo, R. Lord, M. Pourkashanian, Bio-CCS: Cofiring of Established Greenfield and Novel, Brownfield Biomass Resources under Air, Oxygen-enriched Air and Oxy-fuel Conditions, Energy Procedia. 37 (2013) 6062-6069.

[12] S.G. Sahu, N. Chakraborty, P. Sarkar, Coal-biomass co-combustion: An overview, Renew. Sustain. Energy Rev. 39 (2014) 575-586.

[13] Y. Niu, H. Tan, S. Hui, Ash-related issues during biomass combustion: Alkali-induced slagging, silicate melt-induced slagging (ash fusion), agglomeration, corrosion, ash utilization, and related countermeasures, Prog. Energy Combust. Sci. (2015).

[14] M.E. Goerndt, F.X. Aguilar, K. Skog, Drivers of biomass co-firing in U.S. coal-fired power plants, Biomass and Bioenergy. 58 (2013) 158-167.

[15] J. Riaza, R. Khatami, Y.A. Levendis, L. Álvarez, M. V. Gil, C. Pevida, et al., Combustion of single biomass particles in air and in oxy-fuel conditions, Biomass and Bioenergy. 64 (2014) 162-174.

[16] M. Aho, A. Gil, R. Taipale, P. Vainikka, H. Vesala, A pilot-scale fireside deposit study of co-firing Cynara with two coals in a fluidised bed, Fuel. 87 (2008) 58-69.

[17] P. Teixeira, H. Lopes, I. Gulyurtlu, N. Lapa, P. Abelha, Evaluation of slagging and fouling tendency during biomass co-firing with coal in a fluidized bed, Biomass and Bioenergy. 39 (2012) 192-203.

[18] J. Fagerström, E. Steinvall, D. Boström, C. Boman. Alkali transformation during single pellet combustion of soft wood and wheat straw. Fuel Process. Technol. 143 (2016) 204-212.

[19] H. Hagman, R. Backman, D. Boström. Effects on a $50 \mathrm{MW}_{\text {th }}$ Circulating Fluidized-Bed Boiler Co-firing Animal Waste, Sludge, Residue Wood, Peat, and Forest Fuels. Energy \& Fuels. 27 (2013) 6146-6158.

[20] D. Boström, N. Skoglund, A. Grimm, C. Boman, M. Ohman, M. Brostrom, R. 
Backman. Ash transformation chemistry during combustion of biomass. Energy \& Fuels. 26 (2012) 85-93.

570

[21] M. Aho, E. Ferrer, Importance of coal ash composition in protecting the boiler against chlorine deposition during combustion of chlorine-rich biomass, Fuel. 84 (2005) 201-212.

[22] F. Al-Mansour, J. Zuwala, An evaluation of biomass co-firing in Europe, Biomass and Bioenergy. 34 (2010) 620-629.

[23] H. Kassman, L. Bäfver, L.-E. Åmand, The importance of $\mathrm{SO}_{2}$ and $\mathrm{SO}_{3}$ for sulphation of gaseous $\mathrm{KCl}$ - An experimental investigation in a biomass fired CFB boiler, Combust. Flame. 157 (2010) 1649-1657.

[24] H. Kassman, J. Pettersson, B.M. Steenari, L.E. Åmand, Two strategies to reduce gaseous $\mathrm{KCl}$ and chlorine in deposits during biomass combustion Injection of ammonium sulphate and co-combustion with peat, Fuel Process. Technol. 105 (2013) 170-180.

[25] C. Sevonius, P. Yrjas, M. Hupa. Defluidization of a quartz bed - Laboratory experiments with potassium salts. Fuel. 127 (2014) 161-168.

[26] L. Fryda, C. Sobrino, M. Cieplik, W.L. van de Kamp, Study on ash deposition under oxyfuel combustion of coal/biomass blends, Fuel. 89 (2010) 1889-1902.

[27] J. Riaza, M.V. Gil, L. Álvarez, C. Pevida, J.J. Pis, F. Rubiera, Oxy-fuel combustion of coal and biomass blends, Energy. 41 (2012) 429-435.

[28] S. Ahn, G. Choi, D. Kim, The effect of wood biomass blending with pulverized coal on combustion characteristics under oxy-fuel condition, Biomass and Bioenergy. 71 (2014) 144-154.

[29] T. Ekvall, F. Normann, K. Andersson, F. Johnsson, Modeling the Alkali Sulfation Chemistry of Biomass and Coal Co-firing in Oxy-fuel Atmospheres, Energy \& Fuels. 28 (2014) 3486-3494.

[30] T. Ekvall, Alkali sulphation in flames, in: $5^{\text {th }}$ Meeting IEAGHG Int. Oxyfuel Combustion Res. Netw., Wuhan (China), 2015.

[31] N. Jurado, H.G. Darabkhani, E.J. Anthony, J.E. Oakey, Oxy-combustion Studies Into the Co-Firing of Coal and Biomass Blends: Effects on Heat Transfer, Gas and Ash Compositions, Energy Procedia. 63 (2014) 440-452.

[32] Y. Tan, L. Jia, Y. Wu, Some Combustion Characteristics of Biomass and Coal Cofiring under Oxy-Fuel Conditions in a Pilot-Scale Circulating Fluidized Combustor, Energy \& Fuels. 27 (2013) 7000-7007.

[33] L. Duan, Y. Duan, C. Zhao, E.J. Anthony, NO emission during co-firing coal and biomass in an oxy-fuel circulating fluidized bed combustor, Fuel. 150 (2015) 8-13.

[34] L.M. Romeo, L.I. Díez, I. Guedea, I. Bolea, C. Lupiáñez, A. González, et al., Design and operation assessment of an oxyfuel fluidized bed combustor, Exp. Therm. Fluid Sci. 35 (2011) 477-484. 
[35] C. Lupiáñez, L.I. Díez, L.M. Romeo, Influence of gas-staging on pollutant emissions from fluidized bed oxy-firing, Chem. Eng. J. 256 (2014) 380-389.

[36] L.I. Díez, C. Lupiáñez, I. Guedea, I. Bolea, L.M. Romeo, Anthracite oxycombustion characteristics in a $90 \mathrm{~kW}$ th fluidized bed reactor, Fuel Process. Technol. 139 (2015) 196-203.

[37] D.A. Tillman, D. Duong, B. Miller, Chlorine in Solid Fuels Fired in Pulverized Fuel Boilers - Sources, Forms, Reactions, and Consequences: a Literature Review, Energy \& Fuels. 23 (2009) 3379-3391.

[38] J.M. Johansen, M. Aho, K. Paakkinen, R. Taipale, H. Egsgaard, J.G. Jakobsen, et al., Release of $\mathrm{K}, \mathrm{Cl}$, and $\mathrm{S}$ during combustion and cocombustion with wood of high-chlorine biomass in bench and pilot scale fuel beds, Proc. Combust. Inst. 34 (2013) 2363-2372.

[39] R. Hoskinson, D. Karlen, S. Birrell, C. Radtke, W. Wilhelm, Engineering, nutrient removal, and feedstock conversion evaluations of four corn stover harvest scenarios, Biomass and Bioenergy. 31 (2007) 126-136.

[40] C. Lupiáñez, I. Guedea, I. Bolea, L.I. Díez, L.M. Romeo, Experimental study of $\mathrm{SO}_{2}$ and $\mathrm{NO}_{\mathrm{x}}$ emissions in fluidized bed oxy-fuel combustion, Fuel Process. Technol. 106 (2013) 587-594.

[41] L.F. de Diego, A. Rufas, F. García-Labiano, M. de las Obras-Loscertales, A. Abad, P. Gayán, et al., Optimum temperature for sulphur retention in fluidised beds working under oxy-fuel combustion conditions, Fuel. 114 (2013) 106-113.

[42] L. Jia, Y. Tan, E.J. Anthony, Emissions of $\mathrm{SO}_{2}$ and $\mathrm{NO}_{\mathrm{x}}$ during Oxy-Fuel CFB Combustion Tests in a Mini-Circulating Fluidized Bed Combustion Reactor, Energy \& Fuels. 24 (2010) 910-915.

[43] L.F. de Diego, M. de las Obras-Loscertales, A. Rufas, F. García-Labiano, P. Gayán, A. Abad, et al., Pollutant emissions in a bubbling fluidized bed combustor working in oxy-fuel operating conditions: Effect of flue gas recirculation, Appl. Energy. 102 (2013) 860-867.

[44] C. Lupiáñez, L.I. Díez, L.M. Romeo, NO Emissions from Anthracite OxyFiring in a Fluidized-Bed Combustor: Effect of the Temperature, Limestone, and $\mathrm{O}_{2}$, Energy \& Fuels. 27 (2013) 7619-7627.

[45] H. Hosoda, T. Hirama, $\mathrm{NO}_{\mathrm{x}}$ and $\mathrm{N}_{2} \mathrm{O}$ Emission in Bubbling Fluidized-Bed Coal Combustion with Oxygen and Recycled Flue Gas: Macroscopic Characteristics of Their Formation and Reduction, Energy \& Fuels. 12 (1998) 102-108.

[46] F. Scala, R. Chirone, Fluidized bed combustion of single coal char particles at high $\mathrm{CO}_{2}$ concentration, Chem. Eng. J. 165 (2010) 902-906.

[47] L. Duan, C. Zhao, Q. Ren, Z. Wu, X. Chen, NOx precursors evolution during coal heating process in $\mathrm{CO}_{2}$ atmosphere, Fuel. 90 (2011) 1668-1673.

[48] L. Jia, Y. Tan, C. Wang, Experimental Study of Oxy-Fuel Combustion and 
650

651

652

653

654

655

656

657

658

659

660

661

662

663

664

665

666

667

668

669

670

671

672

673

674

675

676

677

678

679

680

[49] L. Duan, C. Zhao, W. Zhou, C. Qu, X. Chen, $\mathrm{O}_{2} / \mathrm{CO}_{2}$ coal combustion characteristics in a $50 \mathrm{~kW}$ th circulating fluidized bed, Int. J. Greenh. Gas Control. 5 (2011) 770-776.

[50] I. Guedea, D. Pallarés, L.I. Díez, F. Johnsson. Conversion of large coal particles under $\mathrm{O}_{2} / \mathrm{N}_{2}$ and $\mathrm{O}_{2} / \mathrm{CO}_{2}$ atmospheres - Experiments and modelling. Fuel Process. Technol. 112 (2013) 118-128.

[51] T. Czackiert, W. Muskala, S. Jankowska, G. Krawczyk, P. Borecki, L. Jesionowski, W. Nowak. Combustible matter conversion in an oxy-fuel circulating fluidized-bed (CFB) environment. Energy \& Fuels 26 (2012) 54375445 .

[52] J.E. Johnsson. Formation and reduction of nitrogen oxides in fluidized-bed combustion. Fuel 73 (1994) 1398-1414.

[53] S. Jiménez, J. Ballester, Formation of alkali sulphate aerosols in biomass combustion, Fuel. 86 (2007) 486-493.

[54] L. Duan, Y. Duan, Y. Sarbassov, Y. Li, E.J. Anthony, $\mathrm{SO}_{3}$ formation under oxy-CFB combustion conditions, Int. J. Greenh. Gas Control. 43 (2015) 172178.

[55] Grimm, M. Öhman, T. Lindberg, A. Fredriksson, D. Brown. Bed agglomeration characteristics in fluidized-bed combustion of biomass fuels using olivine as bed material. Energy \& Fuels. 26 (2012) 4550-4559.

[56] M. Bartels, W. Lin, J. Nijenhuis, F. Kapteijn, J.R. Ommen, Agglomeration in fluidized beds at high temperatures: Mechanisms, detection and prevention. Progress in Energy and Combustion Science. 34 (2008) 633-666.

[57] M.C. Mayoral, J.M. Andrés, M.T. Izquierdo, B. Rubio, Pyrrhotite deposition through thermal projection to simulate iron sulphide slagging in oxyfuel combustion, Fuel. 101 (2012) 197-204.

[58] K. Salmenoja, K. Makela, Superheater corrosion in environments containing potassium and chlorine., J. Inst. Energy. 69 (1996) 155.

[59] E. Furimsky, L. Zheng, Quantification of chlorine and alkali emissions from fluid bed combustion of coal by equilibrium calculations, Fuel Process. Technol. 81 (2003) 7-21. 